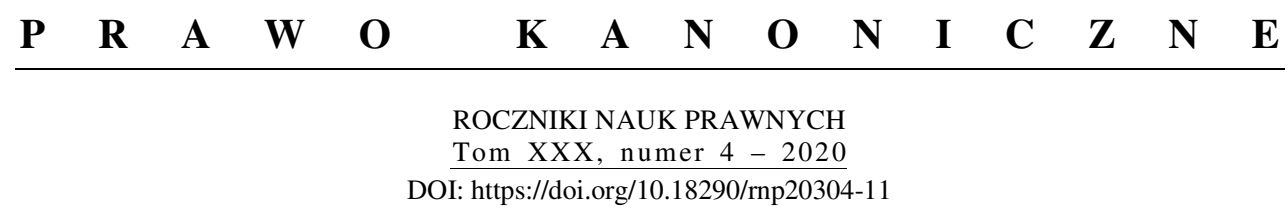

GRZEGORZ LESZCZYŃSKI

\title{
DEPRESSIVE DISORDERS AS A CAUSE FOR CONSENSUAL INABILITY TO CONTRACT A MARRIAGE
}

The act of marriage agreeement, which is a human act, requires consensual ability, which is also called psychological ability from a partner. It is about the ability to take a conscious, deliberative and casual decision. As a cosequence, lack of this ability means the natural incapacity or to put it differently, consensual or psychological inability to eneter into marriage ${ }^{1}$.

It seems that the influence of a major depression on concensual inability to eneter into marriage is the most interesting part from judicature, so in relation to regulations stipulated in can. $1095,2^{\circ}$ i $3^{\circ}$ of the 1983 Code of Canon Law are inevitable to begin an analysis with defining a clinical depression as a disorder, which is defined as a mood disorder by a psychiatrist. The question of the study is: could any depression be a cause of nullity marriage?

\section{CHARACTERISTICS OF DEPRESSIVE EPISODE}

The term depression, which in modern psychiatry replaced the word melancholy, means mood disorder which is marked by the mood decline as well as attenuation of emotional perception. It is considered as some experiences which

Rev. GRZEGORZ LESZCZYŃSKI PhD, Habil. - Head of the Institute of Legal Comparative and Interdisciplinary Research, Faculty of Law and Administration, University of Lodz; address for correspondence: ul. Kopcińskiego 8/12, 90-232 Łódź; e-mail: gleszczynski@wpia.uni.lodz.pl. ORCID: https://orcid.org/00 00-0003-4189-5165.

${ }^{1}$ Cf. W. GóRAlski, G. DzIERżon, Niezdolność konsensualna do zawarcia matżeństwa kanonicznego, Warszawa: Wydawnictwo UKSW 2001, p. 53. 
involve not only mood but also physical, psychological and behavioral experiences, which are defined as a depressive syndrome ${ }^{2}$.

Depressive syndrome is defined as an affective syndrome, which symptoms are connected with the decline of $\operatorname{mood}^{3}$. It is often accompanied by suicide thoughts and plans as an impulsive activity connected with lowering the mood ${ }^{4}$. Some psychological processes are stopped, especially in the context of forms of activities and a track of thought ${ }^{5}$. It is connected with the anxiety and fear. A person that suffers from depression is quiet, unable to work, deprived of sexual desires as well as unable to feel any kind of pleasure ${ }^{6}$.

Among many kinds of depression, there are three main categories. These are somatogenic, psychogenic and endogenous depression ${ }^{7}$. Somatogenic depression appears together with some somatic diseases, some brain organic diseases as well as while being on some medications. Psychogenic depressions are related to various life situations, emotional, occupational and psychic traumas. Endogenous depressions appear together with affective disorders and are connected with endogenous illnesses ${ }^{8}$.

Depressive syndroms that appear in the process of affective disorders, both unipolar and cycloidal are endogenic. Nevertheless, in the field of psychatric, especially in America, it is common to use the name major depression, which is entered to the DSM system. The equivalent to the term major depression in the classification of psychological and behavioral disorders ICD - 10 is the name depressive episode'. Let's try to define some basic symptoms of depressive episode.

\footnotetext{
${ }^{2}$ Cf. C. Hammen, Depresja, trans. M. Trzebiatowska, Gdańsk: Gdańskie Wydawnictwo Psychologiczne 2006, p. 13.

${ }^{3}$ Cf. A. KęPIŃSKI, Melancholia, Warszawa: Wydawnictwo Literackie 1996, p. 7.

${ }^{4}$ Cf. Psychiatria, Vol. I: Podstawy psychiatrii, eds. A. Bilikiewicz, S. Pużyński, J. Rybakowski, J. Wciórka, Wrocław: PZWL 2002, p. 424.

${ }^{5}$ Cf. K. JASPERS, Psicopatologia generale, Roma 1988, p. 640.

${ }^{6}$ Cf. G. ZuAnAzZI, Psicologia e psychiatria nelle cause matrimoniali canoniche, Città del Vaticano: Libreria Editrice Vaticana 2006, p. 140.

${ }^{7}$ Cf. La melanconia: ricerca dell'Università di Firenze sulla patologia dell'umore, eds. C. Faravelli, S. Pallanti, Bologna 1992, p. 19.

${ }^{8}$ Cf. A. GrzYwa, Oblicza psychozy, Lublin: Czelej 2005, pp. 135-136; S. PuŻYŃSKi, Depresje i zaburzenia afektywne, ed. 2, Warszawa: PZWL 1999, p. 25.

${ }^{9}$ Cf. Psychiatria, Vol. II: Psychiatria kliniczna, eds. A. Bilikiewicz, S. Pużyński, J. Rybakowski, J. Wciórka, Wrocław: PZWL 2002, p. 359.
} 


\subsection{Symptoms of depression}

In order to recognize the depressive episode, it is inevitable to distinguish at least five from nine symptoms written below. Mood decline and anhedonia is one of them. These symptoms should last at least for two weeks. Basic symptoms of depressive episodes are: mood decline which last for the most of the day, almost daily, with some hestitations; anhedonia, which is connected with the clear loss of interest or contentmend of almost all activities done for the most of the day, almost every day; weight loss connected with the loss of appetite; sleeeping disorders which characterize with insomnia or on the other hand, the excessive amount of sleep; psychomotor animation or retardation; tiredness and the loss of energy, libido decline; feeling of worthlessness or feeling of being quilty without any reason; reduced activity of thinking and focusing; recurrent thoughts of death or suicide ${ }^{10}$.

In the case of depressive episode there are some basic clinical symptoms that concur on depressive syndrome of three psychological processes: emotional, cognitive as well as motivational, behavioral and somatic disorders.

Among emotional processes, mood decrease is considered to be the main feature of depressive episode as well as decline of psychological and physical activities ${ }^{11}$. Mood decrease come under some hesitations day-to-day, and what is important, it is not related to current happenings ${ }^{12}$. It is vital to notice that mood decline, in the case of depressive episode, is not temporary as in the cases of some traumatic events, but it is a chronic state that last many weeks ${ }^{13}$. It is characterized by not only inability to feel any kind of pleasure, but even inability to express the sadness. In psychiatric, the term anasthesia dolorosa is used to define this state ${ }^{14}$.

Cognitive disorders mainly concern thinking disorders ${ }^{15}$. Some authors claim that depression is the state of thinking disorder to the same extent as it is mood disorder. People that suffer from depression usually think in a negative

\footnotetext{
${ }^{10}$ Cf. Oksfordzki podręcznik psychiatrii, ed. A. Grzywa, Lublin: Czelej 2007, p. 275.

${ }^{11} \mathrm{Cf}$. M. ProfitA, L'incidenza della depressione nelle cause canoniche di nullità del matrimonio: profili medico-legali e probatori, Roma: Lateran University Press 2006, p. 77.

${ }^{12}$ Cf. Klasyfikacja zaburzén psychicznych i zaburzén zachowania w ICD - 10. Opisy kliniczne $i$ wskazówki diagnostyczne, eds., trans. S. Pużyński, J. Wiórka, Kraków-Warszawa: Vesalius 2000, p. 108.

${ }^{13}$ Cf. J.J. GARCÍA FAílde, Nuevo estudio sobre trastornos psíquicos y nulidad del matrimonio, Salamanca: Universidad Pontificia de Salamanca 2003, p. 220.

${ }^{14}$ Cf. J. Rybakowski, Oblicza choroby maniakalno-depresyjnej, Poznań: Temida 2008, pp. 40-41; H. BLESS, Zarys psychiatrii duszpasterskiej, Warszawa: ATK 1980, p. 136.

${ }^{15}$ Cf. P. SARTESCHI, C. MAGGinI, Manuale di psychiatria, Abbiategrasso: Manduzzi 1989, p. 642.
} 
way about themselves as well as the surrounding and the future. They think of themselves as incompetent people and are very critical towards their own abilities. They are not able to reach desired aims and fulfill hopes, that they have ${ }^{16}$. Thinking disorder, in the case of depressive episode, refers to the form and content. Person that suffers from depression has difficulty making decisions, especially important ones connected with their lives. Intensifying the depressive way of thinking can be so enormous that it may appear as a delusion ${ }^{17}$. Delusions that appear during depression, are considered to be antypical, because they come from the mood decrease, anxiety and feeling guilty and most of them can be explained in an understandable, psychopathological way ${ }^{18}$. Suicidal tendencies ${ }^{19}$ are considered to be the consequences of thinking disorders.

Disorders of motivational processes in the depressive episode are connected with the decrease or even the loss of motivation to function. It is connected with being exhausted and with the loss of life energy ${ }^{20}$. Because of the apathy, such person often withdraw from social activities and reduce his or her typical behaviors. Moreover, such person is able to stay in bed for long hours avoiding any kinds of interpersonal relations. Retardation of psychomotor activity is often observed. Breaks, using a few words, monotonous tone of vice and the lack of eye contact are often observed in such person's utterances ${ }^{21}$. What is more, the motion activity is dysfunctional. Majority of people that suffer from depression is not able to work, to do the household chores and some of them are even unable to fulfill their basic needs. Such people are unwilling to go to work. They are afraid of the contact with their colleagues or employers. They do the tasks with the conviction that they do wrong ${ }^{22}$.

The lack of motivation to function is the consequence of circadian rhythm disorder, especially the sleeping part. According to J. Rybakowski sleeping disorders that appear in the depression are typical for this kind of illness. Such person fall asleep fast, with no difficulties, but his or her dream is shallow and

${ }^{16}$ Cf. C. Hammen, Depresja, pp. 14-15.

${ }^{17}$ Cf. J. RYBAKOWsKi, Oblicza choroby, p. 41.

${ }^{18}$ Cf. S. PuŻYŃSKi, Depresje, pp. 27-28.

${ }^{19}$ Cf. J.J. García Fá́lde, Nuevo estudio, p. 220.

${ }^{20}$ Cf. M. Profita, L'incidenza, p. 82.

${ }^{21}$ Cf. C. Hammen, Depresja, p. 16.

${ }^{22}$ Cf. S. PuŻYŃski, Depresje, p. 29. Autor zauważa: „W łagodnych stanach depresyjnych obserwuje się jedynie zmniejszenie liczby kontaktów interpersonalnych, które są zawężone do osób najbliższych (bliskich przyjaciół, rodziny). Chorzy unikają spotkań towarzyskich, zebrań, a zwłaszcza sytuacji, gdy eksponowani są na widok publiczny. Spełnianie czynności, które do tej pory wykonywali rutynowo, takich jak wykład, odczyt, przewodzenie zebraniu, okazuje się często zadaniem przekraczającym ich możliwości”. 
intermittent. As a consequence, it does not bring any kind of regeneration. Such a person wakes up early in the morning with the anxiety about the future ${ }^{23}$. Depression is also connected with the decrease of appetite and as a result the weight loss. As far as sexual needs are concerned, the depressed person does not feel any desires ${ }^{24}$.

\subsection{Intensifying degrees of depression}

According to classification of psychological disorders as well as behavioral disorders ICD - 10 there are four intensifying degrees of depressive episode. These are: mild depressive episode (F 31. 3), moderate depressive episode (F 31. 3), severe depressive episode without psychotic symptoms (F 31.4) and severe depressive episode with psychotic symptoms (F 31. 5) ${ }^{25}$. Mild depressive episode and moderate depressive episode are treated as one of the episode from the same category as the differences between them are inconsiderable. Nevertheless, it should be noticed that only severe depression, which is typical for monopolar and bipolar disorder, is discussed in the classification system DSM - IV. The use of the term severe depression does not mean that this episode does not have different intensifying degrees, which is highlighted by J.J. García Faílde. It only means, that there are such symptoms that unable a person to function normally in the society as well as symptoms that only make it difficult to function ${ }^{26}$.

In accordance with the F 32. 0 category, mild depressive episode is connected with the slight decrease of mood, which last not shorter than two weeks. This episode usually makes it hard to do the work and everyday chores, but it does not distract doing them completely. Moderate depressive episode, described in F 32. 1 category, apart from feature that are typical for mild depressive episode, is characterized also with another symptoms of depression. It is relevant to say that in this case some symptoms are intense and such a person has noticeable difficulties with working and doing day-to-day duties. Neither of these two episodes, both mild and moderate, make a person completely unable to work or do the family chores ${ }^{27}$.

According to the F 32.2 category severe depressive episode without any psychotic symptoms is characterized by three symptoms that appear in mild and moderate episode. What is more, there are four more different symptoms,

\footnotetext{
${ }^{23}$ Cf. J. RYBAKOWSKI, Oblicza choroby, p. 42.

${ }^{24}$ Cf. J.J. García FAílde, Nuevo estudio, pp. 225-226.

${ }^{25}$ Cf. Klasyfikacja zaburzeń psychicznych, pp. 109-111.

${ }^{26}$ Cf. J.J. GARcía FAílde, Nuevo estudio, p. 226.

${ }^{27}$ Cf. Klasyfikacja zaburzeń psychicznych, p. 109.
} 
some of which may reach high intensity. As written in the book, such person evinces noticeable suffering or awakening, until visible inhibition comes. The feeling of worthlessness, low self-assessment, feeling of guilt dominate. Suicide threatening is especially dangerous. There are always somatic symptoms. It is substantial to highlight that severe depressive episode unable performing any kind of work, household chores, apart from minor activities ${ }^{28}$.

In accordance with F 32. 3 category severe depressive episode with psychotic symptoms is characterized with delusions, hallucinations or depressive stupor, apart from symptoms of severe depressive episode without psychotic symptoms. The topic of hallucination is about the sins, poverty, inevitable disaster or crimes. Auditory hallucinations or paranoia are typical for prosecution voices. As a consequence, it may lead even to a stupor ${ }^{29}$.

\section{DEPRESSIVE EPISODE AND CONSENSUAL INCAPACITY TO ENTER INTO MARRIAGE}

The 1983 Code of Canon Law defines the consensual incapacity to enter into marriage in can. 1095. The influence of depressive episode on consensual incapacity to contract marriage need to be considered in some basic aspects ${ }^{30}$. Taking into account the newest judicature, this issue is considered in accordance with can. $1095,2^{\circ}$ and can. $1095,3^{\circ} \mathrm{KPK}$.

\subsection{Depressive episode and grave of discretion of judgement}

The incapacity of matrimonial consent is found in can. $1095,2^{\circ}$ of the code, which is the natural law declaration, assumes that the contractor uses his or her brain efficiently, but also some kind of judgement maturity. It is not only intellect engaged in the formulating such judgement, but also the will cooperates $^{31}$. It is highlighted by W. Góralski in the judicature of Roman Rota both before 1983 and later. There is a visible tendency that point on disorders

\footnotetext{
${ }^{28}$ Cf. Psychiatria, Vol. II: Psychiatria kliniczna, p. 370.

${ }^{29}$ Cf. Klasyfikacja zaburzeń psychicznych, p. 110.

${ }^{30}$ Cf. G. LESZCZYŃSKI, Psychoza maniakalno-depresyjna jako przyczyna niezdolności konsensualnej do zawarcia matżeństwa (kan. 1095, $1^{\circ}-3^{\circ}$ KPK), Łódź: Archidiecezjalne Wydawnictwo Łódzkie 2009, pp. 162-163.

${ }^{31}$ Cf. S. PAŹDZIOR, Przyczyny poważnego braku rozeznania oceniającego w świetle kan. 1095 n. 2 , Lublin: Polihymnia 2004, pp. 15-16.
} 
of intellectual activities as well as volatile ones as a cause for the lack of rater's knowledge ${ }^{32}$.

The term discretio iudicii includes three constitutive elements: intellectual recognition of the subject of the marriage consent, critical judgement and internal freedom that unable to make a decision. Two first elements concern cognitive sphere, the third one concerns volitional power ${ }^{33}$. The serious lack of the knowledge of the rater, as written in sentence coram Pompedda from 25th November 1878 takes place in three cases: lack of ability to get to know the intellectual subject of marriage consent, lack of critical ability and lack of internal freedom which is essential to express marriage consent ${ }^{34}$.

As it has been already seen, Lawmaker does not demand total knowledge of crucial matrimonial laws and duties, but only proportional understanding to the agreement of marriage consent. Proportional criterion discretio iudicii against marriage laws and duties, which are used in judicature, according to W. Góralski the issue is the lack of knowledge on the basis of two parameters: subjective and objective. In the subjective aspect, the lack of knowledge refers to psychological pathologyof the subject. In the objective case it refers to the importance of crucial marriage laws and duties. Taking into account both parameters, which is highlighted by the author, means that in order to confirm consensual inability that results from the lack of knowledge of the rotating in rotational judicature must appear serious anomaly or psychological pathology $y^{35}$.

As we read in the sentence of coram Turnaturi from 20th February 1998, the subject that suffers from severe depression is not able to recognise the marriage consent. What is more, such person is not able to make a critical judgement of the marriage. His decisions and behaviors are characterized by uncertainty, sadness and the reduction of thoughts and will. He lives in the sense of guilt, which has a destructive influence on his judgements of his possibilities as a spouse ${ }^{36}$.

The subjects that suffers from depression does not want to enter into marriage, he feels to be forced to make such decision. He feels that the force

\footnotetext{
${ }^{32}$ Cf. W. GóRALSKI, G. DZIERŻon, Niezdolność konsensualna, p. 157.

${ }^{33}$ Cf. W. GóRALSKI, Niezdolność do zawarcia matżeństwa wedtug kan. 1095, nn. 1-3 kpk. Próba syntezy, „Prawo Kanoniczne” 39 (1996), pp. 25-42; Sent. coram Annè, 26.01.1971, RRD 63, 1971, pp. 66-67; Sent. coram Davino, 5.02.1975, RRD 67, 1975, p. 42; Sent. coram Ragni, 26.11.1985, RRD 77, 1985, p. 545; Sent. coram Jarawan, 24.10.1990, RRD 82, 1990, pp. 716-717.

${ }^{34}$ Cf. Sent. coram Pompedda, 25.11.1978, RRD 70, 1978, pp. 509-510.

${ }^{35}$ Cf. W. GóRAlski, G. DZIERżon, Niezdolność konsensualna, pp. 172-173; Sent. coram Pompedda, 19.05.1994, RRD 86, 1994, p. 208.

${ }^{36}$ Cf. Sent. coram Turnaturi, 20.02.1998, RRD 90, 1998, p. 89.
} 
comes from outside, not realizing that the main problem is his own psychological sphere. As it is read in the sentence of coram Bruno from 15th December 1989 depressive thoughts, which are the result of depressive mood are totally pessimistic. Similarly to maniac episode, in this state the subject is accompanied by hallucinations and other kind of illusions. The nature of them here is really destructive and seriously negative ${ }^{37}$.

The subject that suffers from depression is unable to stay focused. His thinking process is very slow. As it is highlighted by J.J. García Faílde it is not possible that in such state the person is able to notice any kind of positive aspects of the marriage. Furthermore, he is not able to access advantages and disadvantages of such marriage. The thoughts that come to his mind are rather destructive, connected with suicide. There is lack of positive thoughts that concern the act of marriage consent ${ }^{38}$. The only motives that can be noticed by the subject that suffers from depression, as it is written in the sentence of coram Boccafola from 20th April 1989, are negative. They prevent such a person from marriage, but they rather force the subject to avoid such a decision ${ }^{39}$.

So, if the subject that suffers from depressive episode makes the marriage decision, as we read in the sentence of coram Huot from 3rd April 1986, it will be the decision influenced by his negative mood, deprived of critical judgement of the motives ${ }^{40}$.

Sadness and depression which are typical for depressive epiosde have an influence on volatile activities of the contractor ${ }^{41}$. As it has been already noticed, when the person has no psychological disorders, the influence of affectivity is not as strong to make the person unable to self-determination. In the case of a person that is psychologically disordered, the influence of affective factors is determinant ${ }^{42}$.

In the depressive state, as it is written in the sentence of coram Bejan from 10th June 1970, intellect presents only negative motives, without any positive ones that may counterbalance his will depriving the person from the necessary freedom and the ability to self-determination ${ }^{43}$.

${ }^{37}$ Cf. Sent. coram Bruno, 15.12.1989, RRD 81, 1989, p. 766.

${ }^{38}$ Cf. J. J. GARCía FAílde, Nuevo estudio, p. 243.

${ }^{39}$ Cf. Sent. coram Boccafola, 20.04.1989, RRD 81, 1989, p. 297.

${ }^{40}$ Cf. Sent. coram Huot, 3.04.1986, RRD 78, 1986, pp. 219-220.

${ }^{41}$ Cf. Sent. coram Turnaturi, 20.02.1998, RRD 90, 1998, p. 89.

${ }^{42}$ Cf. Sent. coram Fughini, 21.10.1987, RRD 79, 1987, p. 558; Sent. coram Serrano, 29.10.1987, RRD 79, 1987, p. 582; Sent. coram Stankiewicz, 28.05.1991, RRD 83, 1991, p. 345.

${ }^{43}$ Cf. Sent. coram Bejan, 10.06.1970, RRD 62, 1970, pp. 628-629. 
The subject that is in the state of depression and emotional apathy see only negative aspects and motives not seeing any possibility of happiness in his life ${ }^{44}$. Thus, the human will, as we can read in the sentence of coram Bejan from 10th July 1970, stops from choosing marriage. As a result, the marriage is seen as a negative side of reality ${ }^{45}$. The will of such a person, as it has been seen by M. Profita, is limited because of the depressive vision of marriage, which later makes unable person to come from an idea to an act. He is not able to get rid of negative impulses, which make his choice negative, as far as marriage is concerned ${ }^{46}$.

2.2. Depressive episode and incapacity of assuming the essential obligations of matrimony

The incapacity for causes of a psychic nature to take essential matrimonial rights and duties, which is found in can. $1095,3^{\circ}$ of the code means the inability to achieve marriage consent, according to the Roman rule impossibilum nulla obligatio est. It is about the situation, in which the subject is not able to make a decision of a marriage and furthermore, he is not able to take essential matrimonial rights and duties, because of the psychological disorders ${ }^{47}$.

Depressive episode is characterized by the decrease of mood. The subject that is in the state of emotional depression, as it is written in the sentence of coram Colagiovanni from 23rd January 1990, does not feel any kind of interest or pleasure. This state is so permanent that makes unable to take any kind of activities for the period not more than two weeks ${ }^{48}$.

${ }^{44}$ Cf. Sent. Coram Ewers, 4.04.1981, RRD 73, 1981, p. 220: „Ad voluntatem quo spectat quaestio ponitur de libera electione ez parte nubentis adeo ut iste valeat sesje determinare ad intrinseco, perpensis motivis decidendi Hinc inde exstantibus atque cum facultate superandi motivus sive intrinsecus sive affectivitatis".

${ }^{45}$ Cf. Sent. coram Bejan, 10.06.1970, RRD 62, 1970, p. 628; S. PANIzo Orallo, Falta de libertad interna, [in:] Curso de derecho matrimonial y procesal canónico para profesionales del foro, Salamanca: Universidad Pontificia de Salamanca 1986, p. 251; R. ZAVALLONI, La libertà personale. Psicologia della condotta umana, Milano: Vita e Pensiero 1973, p. 262.

${ }^{46}$ Cf. M. Profita, L'incidenza, p. 157; Sent. coram Fiore, 30.05.1987, RRD 79, 1987, p. 341.

${ }^{47}$ Cf. W. GóRALSKI, Kościelne prawo matżeńskie, Warszawa: Wydawnictwo UKSW 2006 , pp. 164-165.

${ }^{48}$ Cf. Sent. coram Colagiovanni, 23.01.1990, RRD 82, 1990, p. 13: ,[...]The essential feature of a Maior Depressive Episode is either depressed mood (or possibly, in children or adolescents, an irritable mood) or loss of interest or pleasure in all, or almost all, activities, and associated symptoms, for a period of at least two weeks. The symptoms represent a change from previous functioning and are relatively persistent, that is, they occur for most of the day, nearly every day, during at least a two-weeks period". 
Feeling of tiredness and the loss of energy is accompanied by the feeling of worthlessness and excessive and unexplained feeling of guilt. In this state, the human will stops from any kind of activities that may lead to matrimonial duties achievement ${ }^{49}$. Depending on the degree of depression, the subject shows minimal interest of a spouse, or does not show it at all ${ }^{50}$.

Alienation, that is typical for depression, means that the subject close himself in his own world of existential suffering. Therefore, such person becomes en egoist who is unable to open on any kind of other person's needs. Making relations with the other person, the subject takes an addictive attitude, which is highlighted by ponens in the sentence of coram Pinto from 28th October 1976, totally submitting the other person's decisions, instead forming requirements concerning love and acceptation ${ }^{51}$. The main problem is with the mutual relation, in which the subject, who is pessimistically oriented towards the life, is only the receiver who is constantly dissatisfied of himself and of other people ${ }^{52}$.

The lack of interest of the other person has the negative influence on the sexual sphere of life. That is why, the subject who decides to enter into marriage in the state of severe depression is not able to obligate himself that the interpersonal relation will be mutual and will based on the mutual agreement in the sexual sphere of life ${ }^{53}$. Thus, it can be stated with the strong possibility that the subject is not able to take both the duty that results from bonum coniugum, as well as bonum polis ${ }^{54}$. The duty of having and bringing up children is the good for the marriage, which is based on the mutual pursuit to create the community involving various spheres of life ${ }^{55}$.

For obvious reasons inability to take up essential matrimonial rights and duties must result from the level of depression, that the subject in the moment of deciding to enter into marriage is not able to take up those duties. It also means that, as it is written in the sentence of coram Pompedda from 11th April 1988 that mild depression does not deprive the subject of the capacity to take up matrimonial duties ${ }^{56}$. In this case, similarly as in the maniac episode, the

\footnotetext{
${ }^{49}$ Cf. Sent. coram Doran, 1.07.1988, RRD 80, 1988, p. 455.

${ }^{50}$ Cf. A. LiŇÁn GARCía, La psicosis maníaco-depresiva y su incidencia en el consentimiento matrimonial, Malaga 2001, p. 191.

${ }^{51}$ Cf. Sent. coram Pinto, 28.10.1976, RRD 68, 1976, p. 390.

${ }^{52}$ Cf. M. Profita, L'incidenza, p. 197.

${ }^{53}$ Cf. R. SzTychmiler, Doktryna Soboru Watykańskiego II o celach matżeństwa i jej recepcja w Kodeksie Prawa Kanonicznego z roku 1983, Lublin: TN KUL 1993, p. 383.

${ }^{54}$ Cf. J. J. GARCÍA FAílde, Nuevo estudio, p. 252.

${ }^{55}$ Cf. H. Stawniak, Uprawnienie-obowiazek zrodzenia $i$ wychowania potomstwa $w$ świetle kanonicznego prawa matżeńskiego, „Prawo Kanoniczne” 32 (1989), No. 3-4, p. 137.

${ }^{56}$ Cf. Sent. coram Pompedda, 11.04.1988, RRD 80, 1988, p. 206.
} 
importance is in the level of depressive disorder and its occurence while entering into marriage ${ }^{57}$.

\section{CONCLUSION}

Depressive episode distinctive for affective disorders, appear by strong mood disorder first. Thinking disorder in the case of depressive episode concerns both retardation of thinking as well as creating the depressive view of the world. The subject has limited recognition abilities, thus it seems that they are not reduced, because apart from the disorder that he suffers from, he is still able to be active intellectually. The most important issue is that he shows emothional indifference. That is why it is impossible to come to a decision of a marriage.

The subject who suffers from depression does not notice positive sides of a marriage, because of thinking retardation. That is why he is not able to judge positive and negative sides of a marriage. Suicide and depressive thoughts accompany him all the time. He perceives the world in a negative way, so it stops him from the decision of a marriage.

The inability for causes of a psychic nature to take up essential matrimonial rights and duties, which is found in can. 1095, $3^{\circ}$ KPK from 1983 means inability to fulfill marriage consent. Alienation, which is typical for depression leads the subject to be closed in his own world of suffering and pain. In the state of depression, it is possible to confirm that the subject is incapable of taking up duty resulting from bonum coniugum, as well as from bonum polis.

\section{BIBLIOGRAPHY}

Sent. coram Bejan, 10.06.1970, RRD 62, 1970, pp. 621-629.

Sent. coram Annè, 26.01.1971, RRD 63, 1971, pp. 66-71.

Sent. coram Davino, 5.02.1975, RRD 67, 1975, pp. 42-47.

Sent. coram Pinto, 28.10.1976, RRD 68, 1976, pp. 382-392.

Sent. coram Pompedda, 25.11.1978, RRD 70, 1978, pp. 508-515.

Sent. coram Ewers, 4.04.1981, RRD 73, 1981, pp. 218-226.

Sent. coram Ragni, 26.11.1985, RRD 77, 1985, pp. 543-557.

Sent. coram Huot, 3.04.1986, RRD 78, 1986, pp. 213-224.

\footnotetext{
${ }^{57}$ Cf. Sent. coram Boccafola, 20.04.1989, RRD 81, 1989, p. 297; Sent. coram Colagiovanni, 8.05.1990, RRD 82, 1990, p. 363.
} 
Sent. coram Fiore, 30.05.1987, RRD 79, 1987, pp. 334-339.

Sent. coram Fughini, 21.10.1987, RRD 79, 1987, pp. 554-567.

Sent. coram Serrano, 29.10.1987, RRD 79, 1987, pp. 573-589.

Sent. coram Pompedda, 11.04.1988, RRD 80, 1988, pp. 198-210.

Sent. coram Doran, 1.07.1988, RRD 80, 1988, pp. 449-464.

Sent. coram Boccafola, 20.04.1989, RRD 81, 1989, pp. 294-306.

Sent. coram Bruno, 15.12.1989, RRD 81, 1989, pp. 763-774.

Sent. coram Colagiovanni, 23.01.1990, RRD 82, 1990, pp. 9-18.

Sent. coram Colagiovanni, 8.05.1990, RRD 82, 1990, pp. 356-363.

Sent. coram Jarawan, 24.10.1990, RRD 82, 1990, pp. 715-721.

Sent. coram Stankiewicz, 28.05.1991, RRD 83, 1991, pp. 342-362.

Sent. coram Pompedda, 19.05.1994, RRD 86, 1994, pp. 206-215.

Sent. coram Turnaturi, 20.02.1998, RRD 90, 1998, pp. 84-99.

BLESS Henryk: Zarys psychiatrii duszpasterskiej, Warszawa: ATK 1980.

GARCía FAílde Juan J.: Nuevo estudio sobre trastornos psíquicos y nulidad del matrimonio, Salamanca: Universidad Pontificia de Salamanca 2003.

GóRALSKI Wojciech: Kościelne prawo małżeńskie, Warszawa: Wydawnictwo UKSW 2006.

GóRALSKI Wojciech: Niezdolność do zawarcia małżeństwa według kan. 1095, nn. 1-3 kpk. Próba syntezy, „Prawo Kanoniczne” 39 (1996), pp. 25-42.

GóRALSKI Wojciech, DZIERŻON Ginter: Niezdolność konsensualna do zawarcia małżeństwa kanonicznego, Warszawa: Wydawnictwo UKSW 2001.

GrzYwa Anna: Oblicza psychozy, Lublin: Czelej 2005.

Hammen Constance: Depresja, trans. M. Trzebiatowska, Gdańsk: Gdańskie Wydawnictwo Psychologiczne 2006.

JASPERS Karl: Psicopatologia generale, Roma 1988.

KĘPIŃSKI Antoni: Melancholia, Warszawa: Wydawnictwo Literackie 1996.

Klasyfikacja zaburzeń psychicznych i zaburzeń zachowania w ICD - 10. Opisy kliniczne i wskazówki diagnostyczne, eds., trans. S. Pużyński, J. Wiórka, Kraków-Warszawa: Vesalius 2000.

La melanconia: ricerca dell'Università di Firenze sulla patologia dell'umore, eds. C. Faravelli, S. Pallanti, Bologna 1992.

LESZCZYŃSKI Grzegorz: Psychoza maniakalno-depresyjna jako przyczyna niezdolności konsensualnej do zawarcia małżeństwa (kan. 1095, 1 - $3^{\circ}$ KPK), Łódź: Archidiecezjalne Wydawnictwo Łódzkie 2009.

LIŇÁN GARCíA Ángeles: La psicosis maníaco-depresiva y su incidencia en el consentimiento matrimonial, Malaga 2001.

Oksfordzki podręcznik psychiatrii, ed. A. Grzywa, Lublin: Czelej 2007.

PANIzO ORALlo Santiago: Falta de libertad interna, [in:] Curso de derecho matrimonial y procesal canónico para profesionales del foro, ed. F.R. Aznar Gil, Salamanca: Universidad Pontificia de Salamanca 1986, p. 239-280.

PAźDzIOR Stanisław: Przyczyny poważnego braku rozeznania oceniającego w świetle kan. 1095 n. 2, Lublin: Polihymnia 2004. 
PROFITA Michela: L'incidenza della depressione nelle cause canoniche di nullità del matrimonio: profili medico-legali e probatori, Roma: Lateran University Press 2006.

Psychiatria, Vol. I: Podstawy psychiatrii, eds. A. Bilikiewicz, S. Pużyński, J. Rybakowski, J. Wciórka, Wrocław: PZWL 2002.

Psychiatria, Vol. II: Psychiatria kliniczna, eds. A. Bilikiewicz, S. Pużyński, J. Rybakowski, J. Wciórka, Wrocław: PZWL 2002.

PUŻYŃSKI Stanisław: Depresje i zaburzenia afektywne, wyd. II, Warszawa: PZWL 1999.

RYBAKOWSKI Janusz: Oblicza choroby maniakalno-depresyjnej, Poznań: Temedia 2008.

SARteschi Pietro, Maggini Carlo: Manuale di psychiatria, Abbiategrasso: Manduzzi 1989.

STAWNIAK Henryk: Uprawnienie - obowiązek zrodzenia i wychowania potomstwa w świetle kanonicznego prawa małżeńskiego, „Prawo Kanoniczne” 32 (1989), No. 3-4, pp. 125-142.

SzTYCHMILER Ryszard: Doktryna Soboru Watykańskiego II o celach małżeństwa i jej recepcja w Kodeksie Prawa Kanonicznego z roku 1983, Lublin: TN KUL 1993.

ZaVAlloni Roberto: La libertà personale. Psicologia della condotta umana, Milano: Vita e Pensiero 1973.

ZuANAZZI Gianfrancesco: Psicologia e psychiatria nelle cause matrimoniali canoniche, Città del Vaticano: Libreria Editrice Vaticana 2006.

\section{DEPRESSIVE DISORDERS AS A CAUSE FOR CONSENSUAL INABILITY TO CONTRACT A MARRIAGE}

\section{Summary}

Taking up the issue of depresion as a cause for declaring a marriage null and voit, the author begins his reflections with a look at depressive episode. From the point of view of marriage validity, of special significance is also the analysis of depresion with very particular medical aspects. The cause of nullity of a marriage discussed here, in turn, requires a rather precise definition of depresion and the factors by which it may be triggered. The last part of the author's reflections is devoted to the analysis of canon 1095 of the Code of Canon Law, especially to the definition of cases when this depresion is serious enough to exclude marriage validity.

Key words: The marriage; matrimonial consent; depresion; incapacity

\section{ZABURZENIA DEPRESYJNE \\ JAKO PRZYCZYNA NIEZDOLNOŚCI KONSENSUALNEJ DO ZAWARCIA MAŁŻEŃSTWA}

\section{Streszczenie}

Akt zgody małżeńskiej, będący aktem ludzkim, wymaga od kontrahenta zdolności konsensualnej, zwanej też zdolnością psychiczną. Chodzi tu o zdolność do powzięcia świadomej, rozważnej i swobodnej decyzji odnoszącej się do zawarcia małżeństwa. W konsekwencji brak tej zdolności oznacza niezdolność naturalną albo inaczej: konsensualną lub psychiczną do 
zawarcia małżeństwa. Określenie wpływu silnej depresji na niezdolność konsensualną do zawarcia małżeństwa wydaje się najbardziej interesujące $\mathrm{z}$ punktu widzenia aktualnej doktryny i orzecznictwa, a więc w odniesieniu do przepisów zawartych w kan. 1095, $2^{\circ}$ i $3^{\circ}$ Kodeksie Prawa Kanonicznego z 1983 r. Pytanie, które należy jednak postawić, jest następujące: czy każda depresja skutkuje niezdolnością psychiczną do wyrażenia zgody małżeńskiej czy, też jedynie ogranicza tę wolę nie powodując nieważności małżeństwa? Niniejszy artykuł jest próbą odpowiedzi na tak postawione pytanie.

Słowa kluczowe: małżeństwo; zgoda małżeńska; depresja; niezdolność 